\title{
PLA Expeditionary Capabilities and Implications for the United States Asia Policy
}

Kristen Gunness

RAND Office of External Affairs

CT-452

January 2016

Testimony presented before the U.S.-China Economic and Security Review Commission on January 21, 2016

This product is part of the RAND Corporation testimony series. RAND testimonies record testimony presented by RAND associates to federal, state, or local legislative committees; government-appointed commissions and panels; and private review and oversight bodies. The RAND Corporation is a nonprofit research organization providing objective analysis and effective solutions that address the challenges facing the public and private sectors around the world. RAND's publications do not necessarily reflect the opinions of its research clients and sponsors. RAND ${ }^{\circledR}$ is a registered trademark. 
For more information on this publication, visit www.rand.org/pubs/testimonies/CT452.html

Published by the RAND Corporation, Santa Monica, Calif.

(C) Copyright 2016 RAND Corporation

RAND $^{\circledR}$ is a registered trademark

\section{Limited Print and Electronic Distribution Rights}

This document and trademark(s) contained herein are protected by law. This representation of RAND intellectual property is provided for noncommercial use only. Unauthorized posting of this publication online is prohibited. Permission is given to duplicate this document for personal use only, as long as it is unaltered and complete. Permission is required from RAND to reproduce, or reuse in another form, any of its research documents for commercial use. For information on reprint and linking permissions, please visit www.rand.org/pubs/permissions.html.

The RAND Corporation is a research organization that develops solutions to public policy challenges to help make communities throughout the world safer and more secure, healthier and more prosperous. RAND is nonprofit, nonpartisan, and committed to the public interest.

RAND's publications do not necessarily reflect the opinions of its research clients and sponsors.

\section{Support RAND}

Make a tax-deductible charitable contribution at www.rand.org/giving/contribute

www.rand.org 


\section{Kristen Gunness ${ }^{1}$ \\ The RAND Corporation}

\section{PLA Expeditionary Capabilities and Implications for United States Asia Policy ${ }^{2}$ \\ Before the U.S.-China Economic and Security Review Commission}

January 21, 2016

Thank you Co-Chairs Fiedler and Wortzel, members of the Commission, and staff. It is an honor to testify here on issues of importance to the United States and the future stability of the Asia-Pacific region. In this testimony, I will address the potential benefits and problems that joint People's Liberation Army (PLA) expeditionary capabilities present for the United States, particularly as they relate to concerns and opportunities for U.S. Asia policy and U.S. military operations.

China's expanding interests increasingly require a capacity to provide security for investments and business ventures around the globe, including millions of People's Republic of China (PRC) citizens living abroad, access to energy and other natural resources, and continued access to critical shipping lanes. PRC leaders perceive a need to both protect global interests and participate in future humanitarian and disaster relief responses. To this end, the PLA has engaged in missions far from its borders, including humanitarian assistance and disaster response, noncombatant evacuation operations, and sea-lines of communication protection. Alongside development of a variety of capabilities necessary to conduct these missions, China's actions to shape the international security environment are accelerating, posing both opportunities and challenges for U.S. policymakers.

\section{PLA Expeditionary Capabilities in Context}

While not the primary focus of this testimony, the first step in considering U.S. Asia policy and military implications involves assessing the expeditionary capabilities that the PLA is augmenting or newly developing, and how those capabilities fit into the PLA's overall modernization program. Briefly, I have three key points to underscore about the current state of the PLA that have direct bearing on the development of expeditionary capabilities and how the Chinese military will use them:

\footnotetext{
${ }^{1}$ The opinions and conclusions expressed in this testimony are the author's alone and should not be interpreted as representing those of RAND or any of the sponsors of its research. This product is part of the RAND Corporation testimony series. RAND testimonies record testimony presented by RAND associates to federal, state, or local legislative committees; government-appointed commissions and panels; and private review and oversight bodies. The RAND Corporation is a nonprofit research organization providing objective analysis and effective solutions that address the challenges facing the public and private sectors around the world. RAND's publications do not necessarily reflect the opinions of its research clients and sponsors.

${ }^{2}$ This testimony is available for free download at http://www.rand.org/pubs/testimonies/CT452.html.
} 
1) The PLA is at the beginning of an extensive reorganization involving significant structural, political, and cultural changes, which ultimately will affect both what the PLA can do and how well it can do it. ${ }^{4}$

2) China's military reorganization is occurring in the context of other major national political changes as Xi Jinping further consolidates power and institutes centralization of authority-a move likely designed to assert greater national authority over the PLA and curb corruption in the military leadership. ${ }^{5}$

3) Evaluating the PLA's level of capabilities and direction, expeditionary or otherwise, is therefore a moving target that will require continuous assessment and reassessment as the military reorganization unfolds.

Further, what constitutes "expeditionary capabilities" to the PLA? While the PLA has for at least a decade been in the process of acquiring a range of capabilities in order to operate further abroad, potential regional contingencies requiring robust anti-access/area denial or "counter-intervention" capabilities still dominate China's security agenda and constitute the bulk of its military modernization efforts. With tensions on the rise over regional territorial disputes, the recent Taiwan elections, and Chinese concerns about increased U.S. presence in the region as a result of the rebalance to Asia, this focus on regional anti-access/area denial capabilities is unlikely to wane in the near future.

Thus, many of the expeditionary capabilities that the PLA is investing in or improving are what could be considered "overlap" capabilities that are useful across a range of mission sets, including antiaccess/area denial, cross-border, and expeditionary missions. Examples of such capabilities include building and upgrading the PLA Navy (PLAN)'s surface warfare and amphibious ship fleets, attack and bomber aircraft, and nuclear attack submarines; investing in rapid reaction forces, such as China's marine, airborne, and special operations forces; honing the PLA's military airlift and sealift capabilities; and investing in long-range strike assets.

In addition to these overlap capabilities, the PLA is newly developing expeditionary capabilities to operate further abroad. These include the ongoing construction of China's aircraft carriers; augmentation of the PLA's at-sea replenishment capabilities, which are necessary to operate abroad on longer missions, given that China lacks overseas bases; and development of a range of space-based capabilities inherent to an "informatized" or networked force, to include communication and navigation satellites for positioning, as well as satellites for providing intelligence, surveillance, and reconnaissance to the PLA. Finally, the

\footnotetext{
${ }^{4}$ Wang Shibing and An Puzhong, "China's New Central Military Commission Established," China Military Online, January 11, 2016.

${ }^{5}$ David Ignatius, "China's Xi Jinping Consolidates Power and Brings Stability," Washington Post, February 28, 2014. As of January 13, 2016: http://www.washingtonpost.com/opinions/david-ignatius-chinas-xi-jinping-consolidatespower-and-brings-stability/2014/02/28/3280148a-9ff7-11e3-9ba6-800d1192d08b_story.html
} 
recent announcement of a planned PLA logistics base in Djibouti, along with ongoing negotiations for greater port access and investment in port and logistics infrastructure around the globe, illustrates that Chinese leaders are building the type of strategic partnerships necessary for global expeditionary operations. $^{6}$

When assessing the PLA's level of expeditionary capability, we must consider that some of the skills that the PLA needs for expeditionary missions have been used for years for nonexpeditionary missions, while other capabilities are relatively new. In addition, the PLA has more practice with some mission sets than others (such as counter-piracy). ${ }^{7}$ The PLA also is still in the process of integrating technologies critical to becoming a modern force-including an ongoing and evolving training program for personnel to operate new weapons and equipment. The outcome is a military with uneven levels of ability in general, and expeditionary capabilities are no exception; the PLA is able to conduct some types of missions better than others, and is still limited overall in what it can do in a global expeditionary capacity.

\section{Two Concerns and Two Opportunities for U.S. Asia Policy}

- How could the development of PLA expeditionary/force projection capabilities affect the U.S. rebalance to Asia and the U.S. Asia-Pacific Maritime Security Strategy?

The PLA's development of both the "overlap" and "new" capabilities required to focus on regional contingencies and protect global interests presents several concerns and opportunities for U.S. Asia policy.

\section{Concern 1}

First, the further development of expeditionary capabilities likely will expand China's military options for responding to both global and regional threats. Augmented sea and airlift, advanced special operations force capabilities, a larger number of surface vessels and aircraft, and overseas military operational experience could lead Beijing to be more willing to consider the use of force, although it is unlikely that it would use force unilaterally outside of the Asia-Pacific region. In addition, greater numbers of PLAN patrols in the South China Sea and beyond mean that U.S. and Chinese forces are operating in closer contact than ever before-raising the risk of miscalculation or escalation should an incident occur.

\footnotetext{
${ }^{6}$ Sam LaGrone, "U.S. AFRICOM Commander Confirms Chinese Logistics Base in Djibouti," USNI News, November 25, 2015. As of January 13, 2016: http://news.usni.org/2015/11/25/u-s-africom-commander-confirms-chineselogistics-base-in-djibouti

${ }^{7}$ The PLA now has significant experience in counter-piracy operations because of its participation in patrols in the Gulf of Aden. However, learning to conduct and maintain those operations took many years. See Kristen Gunness and Sam Berkowitz, "PLA Navy Planning for Out of Area Deployments," in Andrew Scobell, Arthur S. Ding, Phillip C. Saunders, and Scott W. Harold, eds., The People's Liberation Army and Contingency Planning in China, Washington, D.C.: National Defense University Press, 2015. As of January 13, 2016:

http://ndupress.ndu.edu/Portals/68/Documents/Books/PLA-contingency/PLA-Contingency-Planning-China.pdf
} 
This is particularly concerning because an area of recent policy shift involves PRC leadership's increasingly hardened stance regarding core interests. For example, in 2013, Xi Jinping pledged that China would not "compromise an inch" of any of its territorial and sovereignty claims. ${ }^{8}$ In June 2015 , China enacted a sweeping security law intended to protect its core interests, including defending sovereignty claims and territorial integrity. ${ }^{9}$ Beijing also has demonstrated a growing willingness to "impose costs" to deter countries from impinging on PRC core interests. Examples include the PRC restriction on imports of Philippine bananas in response to the Scarborough Reef crisis and the freezing of high-level diplomatic activity for a year in response to British Prime Minister David Cameron's meeting with the Dalai Lama. These activities have so far been primarily nonmilitary in nature and are seen by China as efforts to manage crises and deter further escalation into the military realm. However, the development of PLA expeditionary capabilities, particularly the "overlap" capabilities that also can be used for anti-access/area denial missions, adds greater tools for potential coercive force.

\section{Concern 2}

A second concern for U.S. policymakers on Asia is that China could increasingly use a PLA expeditionary force to shape the security environment, create greater competition for the United States, or involve itself in regional matters (and beyond) that are either counter to or a hindrance to U.S. goals and objectives. Possible examples of increased influence or competition that could deter nations from closer relations with Washington include Chinese-led multilateral exercises to strengthen Beijing's relations with other countries and port access agreements that provide the host country with tangible financial benefits. While this type of influence tug-of-war already occurs, the development of PLA expeditionary capabilities could create greater competition for the United States in the region and globally.

In addition, China's desire to uphold stability over other factors, such as human rights, may conflict with that of the United States when attempting to influence the security environment with expeditionary capabilities. Beijing's support of Pyongyang despite numerous security and humanitarian concerns is a regional example of this.

\footnotetext{
${ }^{8}$ Timothy R. Heath, "Diplomacy Work Forum: Xi Steps Up Efforts to Shape a China-Centered Regional Order," China Brief, Vol. 13, No. 22, November 7, 2013. As of January 13, 2016:

http://www.jamestown.org/programs/chinabrief/single/?tx_ttnews\%5Btt_news $\% 5 \mathrm{D}=41594 \& t x \_t t n e w s \% 5 B b a c k P i d \% 5$ $\mathrm{D}=688$ \&no_cache $=1 \#$

${ }^{9}$ Edward Wong, "Security Law Suggests a Broadening of China's Core Interests," New York Times, July 2, 2015. As of January 13, 2016: http://www.nytimes.com/2015/07/03/world/asia/security-law-suggests-a-broadening-of-chinascore-interests.html?_r=0
} 


\section{Opportunity 1}

A PLA with expeditionary capabilities would be able to increasingly provide services that other global navies deliver, such as rapid humanitarian assistance and disaster response, regional counter-piracy patrols, and protection of regional sea lines of communication. The ability to provide such public goods is important to Beijing as it seeks to enhance its image as a great power and to allay fears and mistrust by reassuring its neighbors of benevolent intent. Additionally, China has interests not to encourage or provoke the formation of balancing coalitions among its neighbors and extra-regional great powers, such as the United States. This creates increased opportunities for U.S. leaders to encourage Chinese involvement in regional cooperative efforts, such as those listed above, as well as presenting more occasions for U.S. and Chinese forces to work together on issues of mutual security concern.

\section{Opportunity 2}

Another policy opportunity for the United States relates to the reaction of Asian allies and partners to a more robust PLA expeditionary force. A more assertive China with expeditionary capability could lead nations in the region to be more receptive to supporting U.S. efforts to shape the security environment, and to U.S. objectives in Asia. This could specifically be an opportunity to sway those nations that are leery of fully supporting U.S. efforts because of China's influence-be it monetary, cultural, or military. Nations such as Thailand, Malaysia, and India (should China build a base in Pakistan) potentially fall into this category and could be receptive to increased dialogue with the United States.

\section{Opportunities and Concerns for the U.S. Military}

- What opportunities might exist for emerging PLA expeditionary capabilities to contribute to supporting regional security operations? What expeditionary/force projection capabilities may develop that would pose operational concerns for U.S. presence in the Asia-Pacific area of responsibility?

PLA expeditionary capabilities allow greater opportunities for the U.S. and Chinese militaries to cooperate on regional issues of mutual security concern. In addition, expeditionary missions-such as counterpiracy operations in the Gulf of Aden, United Nations peacekeeping missions, and noncombatant evacuation operations-allow the PLA to gain critical operational experience that then translates to a more experienced force at home, potentially enabling a greater ability to work alongside more technologically advanced militaries to contribute to security in the Asia region.

Potential regional PLA security missions are mainly maritime in focus and include humanitarian assistance and disaster relief, counter-piracy operations and escort missions (particularly relevant given 
the uptick in piracy in Southeast Asia), and contributions to countering drug and human trafficking. The U.S. Navy and the PLAN are well-positioned to conduct cooperative exercises and security operations on maritime issues, because there is already a relatively robust security dialogue and military-to-military exchange between the two services.

The U.S. Navy and the PLAN already participate in cooperative security efforts elsewhere in the world, which has even led to the occasional low-level military exercise-for example, in the Gulf of Aden, where the two navies conducted an exercise to land helicopters on each other's ships for the first time. ${ }^{10}$

Ongoing dialogue between U.S. Navy and PLAN leadership has focused on creating additional U.S. port visits for PLAN ships, creating additional Chinese port visits for U.S. ships, and extending invitations to participate in each other's exercises, such as the Rim of the Pacific. ${ }^{11}$

One of the most significant operational concerns for the U.S. military regarding China's expeditionary capabilities involves the potential for miscalculation given more-numerous encounters between the militaries in the region and abroad, particularly in the maritime domain. In addition, China's assertiveness over regional territorial claims and the likelihood of the U.S. Navy conducting additional Freedom of Navigation operations create a greater possibility of an incident occurring. The U.S. Navy and PLAN are attempting to mitigate these risks by implementing a Code for Unplanned Encounters at Sea; however, this will take time to integrate into both navies' operational procedures. ${ }^{12}$

Another operational concern is the PLA's investment in command, control, communications, computers, and ISR (C4ISR); counter-C4ISR; and space-based capabilities, many of which are necessary in order to be networked and operate over long distances. Specifically, the PLA has increased its ISR range, particularly around the region and over long distances, including locations where territorial disputes exist. The PLA's ISR capabilities are further augmented by the advancement of unmanned aerial vehicles that can conduct reconnaissance over long distances and can be used in regional humanitarian assistance and disaster relief missions. ${ }^{13}$ While more-robust C4ISR capabilities are a natural outgrowth of the PLA's modernization and expeditionary capabilities, this also means that U.S. military operations could be under increasing surveillance from the PLA.

\footnotetext{
${ }^{10}$ Hendrick Simoes, "U.S. Navy Seeks More Cooperation with China in Counter Piracy Exercise," Stars and Stripes, August 26, 2013. As of January 13, 2016: http://www.stripes.com/news/navy/us-navy-seeks-more-cooperation-withchina-in-counter-piracy-exercise-1.237354

${ }^{11}$ Chief of Naval Operations Public Affairs, "CNO's Visit Builds Cooperation for Greater US, PLA Navy Relationship," U.S. Navy, Story Number: NNS140721-03, July 21, 2014. As of January 13, 2016: http://www.navy.mil/submit/display.asp?story_id=82324

12 Lauryn Dempsy, "USS Fort Worth Conducts CUES with Chinese Navy," U.S. Navy, Story Number: NNS150226-11, February 26, 2015. As of January 13, 2016: http://www.navy.mil/submit/display.asp?story_id=85767

${ }^{13}$ Michael S. Chase, Kristen A. Gunness, Lyle J. Morris, Samuel K. Bekowitz, and Benjamin S. Purser III, Emerging Trends in China's Development of Unmanned Systems, Santa Monica, Calif.: RAND Corporation, RR-990-OSD, 2014. As of January 13, 2016: http://www.rand.org/pubs/research_reports/RR990.html
} 


\section{Implications for U.S. Policymakers}

Focus on Crisis Management: One implication for U.S. Asia policy is the critical need to focus on crisis and escalation management in the Asia-Pacific region. U.S. policymakers should work to develop a broad range of scenarios to support crisis planning. As noted previously, a China with a robust expeditionary capacity may have a higher threshold for risk than the United States or be emboldened by such capabilities, particularly when it comes to defending its territorial interests in the South China Sea or Spratly Islands, for example. U.S. planning for a crisis with China should take this into account. Increased collaboration with China and our allies and partners to study crisis management methods, through either Track 1.5 or Track 2 dialogues, would help to better inform strategic government-to-government dialogue and should be considered a part of our overall Asia security strategy.

\section{Maximize Cooperation on Areas of Mutual Security Concern: Despite the United States and PRC being} increasingly at odds with each other on many issues, there remain a host of security concerns on which the two can cooperate as part of the United States' rebalance strategy, particularly as the PLA hones certain expeditionary capabilities. Humanitarian assistance and disaster relief remains an obvious choice for potential joint or multilateral exercises, or cooperation should disaster strike the region. Regional multilateral counter-piracy patrols, as in the Gulf of Aden, could be another area of cooperation, as piracy in Southeast Asia, and specifically the Strait of Malacca, is once again on the rise. ${ }^{14}$ These types of cooperative efforts would also contribute to assisting with crisis management, because they would contribute to operational awareness and encourage continued dialogue.

Balance U.S. Presence and Clear Regional Priorities: Increased expeditionary capabilities mean that China will soon be able to deliver some of the public services that the U.S. military traditionally provides in the region. It also means that the PLA is more visible both in the region and abroad. For example, the PLAN's patrols in the South China Sea are now routine, and forays beyond the first island chain and into the Indian Ocean are becoming more frequent.

U.S. policymakers should consider priorities for regional military and nonmilitary engagement in Asia, given that the U.S. military is no longer the sole provider of regional security. In an era of constrained resources, the necessity of maintaining a steady, visible presence in the region, including conducting regular exercises with allies and partners (and with the Chinese, if feasible) and potentially more-frequent Freedom of Navigation operations to protect maritime rights, must be balanced with comprehensive softpower engagement. Clear priorities in both of these areas can greatly contribute to regional stability and help maintain U.S. influence and partnerships.

\footnotetext{
14 “Malacca Buccaneers," The Economist, July 27, 2015. As of January 13, 2016: http://www.economist.com/news/asia/21656237-step-aside-somalia-south-east-asia-new-piracy-capital-worldmalacca-buccaneers
} 